\title{
Quid est veritas? Augustinus oor waarheid en leuen - en latere ontwikkelings ${ }^{1}$
}

\author{
J H van Wyk \\ Departement Dogmatologie \\ Potchefstroomse Universiteit vir Christelike Hoër Onderwys
}

\begin{abstract}
Quid est veritas? Augustine on truth and lying - and the aftermath

In this article the author investigates the (very difficult) issue of truth and lying. What does it mean to speak the truth and when does a person tell a lie? The Augustinian as well as post-Augustinian views are enumerated and some of the main truth theories evaluated. In conclusion the author tries to make a final assessment and to open new ways of thinking the truth. Truth is a multidimensional category which should never be over-simplified.
\end{abstract}

\section{PROBLEEMSTELLING}

Die vraag van Pilatus, wat is waarheid?, bly deur alle eeue deur aktueel. Dit raak die regspraktyk want regters wil weet wat die waarheid is voordat hulle ' $n$ regverdige oordeel kan uitspreek. Die vraag is ook vir die pastoraat en mediese beroep belangrik: behoort die pastor of dokter aan 'n terminale kankerpasiënt "die waarheid te vertel"? aan ' $n$ aangenome kind vertel te word wie sy of haar biologiese vader en moeder is? Ook vir die etiek is die vraagstelling van belang soos blyk uit gebeure tydens die Tweede Wêreldoorlog toe beskermhere voor die vraag te staan gekom het of hulle teenoor Duitse

\footnotetext{
' Graag maak ek van die geleentheid gebruik om kollega Johan Koekemoer geluk te wens met hierdie mylpaal in sy bediening asook vir sy bydrae tot die uitbou van die teologie. Mag hy en sy gesin die seën van die Here ondervind op sy verdere lewensweg.

2 Vergelyk Geesink (1931:440); Wurth (1957:274); Thielicke (1965:171-189); Van Wyk (1967:8-9); Heyns (1970:237); De Bruyn (1998:237-238); vgl verder Smelik (1967:167-174); Velema (1971:51-57); Durand (1977:73-80); Lochman (1979:137-141): Douma (1997:130-134).
} 
informante "die waarheid moes praat" in verband met Joodse onderduikers (vgl Thielicke 1965:122-145). Behoort 'n vrou wat 'n affair gehad en dit ter wille van die behoud van haar huwelik laat vaar het, vir haar man daarvan te vertel (Smedes 1983:234-237)? Wat behoort alles in getuigskrifte opgeneem of weggelaat te word (vgl Van Wyk 1986:119. 116)? Mag die polisie van leuens gebruik maak om dwelmhandelaars en landsverraaiers te ontmasker? 'n Bisarre voorbeeld: behoort 'n prostituut wat aan vigs ly, dit aan haar "kliënte" mee te deel?

Ook vir die politiek is die vraag na waarheid en leuen van groot belang (vgl Thielicke 1965:145-171). Hoeveel waarheid en leuens het politieke leiers Gor apartheid vertel? Die vraagstelling het nuwe aktualiteit verkry rondom die werk van die Waarheiden Versoeningskommissie ( vgl Du Toit 1997:939-955). Het diegene wat voor die Waarheids- en Versoeningskommissie getuienis gelewer het, "die waarheid gepraat", veral dié wat vir amnestie aansoek gedoen het? Wat beteken dit "om die waarheid te praat"? Kom dit neer op 'n juiste mededeling van feite en gebeure wat in die verlede plaasgevind het? Wat is waarheid?

Die groot kerkvader uit Noord-Afrika, Aurelius Augustinus (354-430), het die temas van waarheid en leuen in talle van sy geskrifte aangeraak. Soos die berg Kilimandjaro bo die Afrikaanse landskap uittroon, so troon die figuur van Augustinus uit bo die teologiese landskap van Afrika en die Westerse wêreld. Daar is haas geen enkele dogma van die kerk oor die wêreld waarin sy invloed nie sigbaar en sy bydrae opvallend is nie. Nie net is sy dogmatiese bydrae oorweldigend nie, maar ook sy etiese insigte verdien steeds besondere aandag, veral ten opsigte van 'n tema waar dogmatiek en etiek mekaar ten nouste raak, soos in die geval van waarheid en leuen. Kan ons hierin nog van Augustinus leer?

Die doel van hierdie artikel is om die insigte van Augustinus na te gaan, te let op die na-Augustiniaanse ontwikkeling, enkele belangrike waarheidsteorieë te ondersoek, en af te sluit met 'n moontlike antwoord en 'n konklusie. 


\section{AUGUSTINUS OOR WAARHEID EN LEUEN}

\subsection{Augustinus oor waarheid}

Augustinus het in verskeie van sy geskrifte, selfs van sy vroegste geskrifte, die waarheidsvraag aangeraak. Hy was sy lewe lank 'n soeker na die waarheid (Soliloquia 2.26). Tereg is opgemerk: "Augustin hat wie kein anderer christlicher Denker im ersten Jahrtausend die zentrale Bedeutung des Wahrheitsproblems erkannt" (Möller 1971:32; vgl Rief 1961:282-318). Sy belangstelling in die waarheid blyk veral duidelik in sy vroeë geskrif Contra Academicos (386).

Ten einde Augustinus se afwysing van die skeptisisme (wat hom in 'n stadium nogal geboei het) goed te begryp, moet dit verstaan word teen die agtergrond van die Griekse denke. Sokrates en Plato het aanvaar dat waarheid bestaan, maar dat filosofiese waarhede onbereikbaar is en net vaagweg geken kan word (Curley 1997:36-38). Waar die Stoïsyne redelike kennis aanvaar het, het die skeptici beweer dat geen ware kennis moontlik is nie en dat menslike kennis nie verder kom as die waarskynlike nie. Augustinus voer in Contra Academicos (3.15.33-36) aan dat so 'n standpunt nie net onvoldoende is nie, maar ook gevaarlik. Hy rig hom in hierdie geskrif teen die akademici (Cicero, Sokrates, Plato en Zeno) en sit sy siening oor sekerheid en waarheid uiteen (vgl Horn 1995:39-43). Hy voer aan dat waarheid en geluk met mekaar in verband gebring behoort te word: is dit moontlik vir ' $n$ mens om gelukkig te wees indien jy nie kennis van die waarheid besit nie? Die hele argument van die akademici stort in duie omdat hulle enersyds aanvaar dat ' $n$ mens verstandig/wys kan wees, maar andersyds geen sekere kennis kan besit nie. Volgens Augustinus kan die menslike rede sekerheid verkry deur middel van die beginsel van kontradiksie - 'n ding kan nie tegelykertyd bestaan en nie bestaan nie. Elkeen wat twyfel, weet dat iets waar is, naamlik dat hy twyfel (vgl De vera religione 39.73). Waarheid kan gevind word deur middel van die menslike rede en die aanvaarding van gesag. Matematiese waarheid is byvoorbeeld 'n waarheid (Contra Academicos 3.11.25). Die waarheid kan gevind word, want die waarheid is geopenbaar. Daarby is die argumente van die skeptici ook inkonsistent (Curley 1997:105-108). Om te beweer, soos die akademici doen, dat menslike kennis waarskynlik is, is reeds 'n 
waarheidsuitspraak (Contra 2.7.16). Augustinus se kritiek was van so 'n hoë niveau (Horn 1995:42) en so vernietigend dat die skeptici vir tien eeue na hom verdwyn het.

Ook in sy ander geskrifte gaan Augustinus in op die waarheidsvraag. Waarheid, wysheid en geluk is vir hom onafskeibare groothede. In De beata vita (386) beskou hy wysheid en waarheid as feitlik sinoniem en stel hy dat dit te vind is in Christus die Seun van God (4.34). Wie deur die Waarheid tot die hoogste maat gekom het, is gelukkig wat beteken om God te besit en te geniet (4.34). In sy Soliloquia (387) onderskei Augustinus tussen waarheid (veritas) en waarwees (verum) (1.27). Al sterf 'n ware ding, die waarheid kan nooit sterf nie, die waarheid is onsterflik en onverganklik - 'n telkens terugkerende gedagte $(1.28 ; 2.2 ; 2.28 ; 2.33)$. Die waarheid is dus nie in sterflike dinge te vind nie (1.29). In boek 2 hou hy hom veral besig met die vraag hoe die waarheid geken kan word en wat die kenmerke van waarheid is. ' $n$ Mens kom op die spoor van die waarheid deur na te gaan wat onwaar is; onware dinge bestaan in bedrieglikheid en leuenagtigheid. Volgens Augustinus is daar geen beter manier om die waarheid te soek as deur te vra en te antwoord nie (2.14).

In sy De vera religione (389) betoog Augustinus dat die waarheid alle dinge wat waar is, waar maak (36.66). Die volmaakte waarheid word nie in uiterlike dinge gevind nie omdat sulke dinge veranderlik is; die waarheid woon in die innerlike mens (39.72) wat egter oorstyg en gerig moet word op die waarheid. Die waarheid word nie deur redenering gevind nie; die rede skep nie die waarheid nie, maar ontdek slegs die (bestaande) waarheid (39.73). Die summa veritas is God, is die Woord, van die begin af by God (36.66). Die waarheid is die innerlike lig waardeur ons God ken (55.113). Waarheid word só langs die weg van (verligte) introspeksie bereik, maar dan beteken inkyk tegelyk ook opkyk (Rist 1999:70-71, 88-89; vgl Vrielink 1956:17-20). Niks belemmer die sig op die waarheid meer as lusgevoelens en valse beelde van die sigbare dinge nie en daarom moet ' $n$ mens innerlik gereinig word om die onveranderlike vorme van die dinge te sien (3.3); niemand is gereed vir die koninkryk van God as hy of sy nie vleeslike verhoudings haat nie (46.88).

In sy latere geskrifte resoneer hierdie gedagtes. Die Confessiones (397-401) stel dat die geluksalige lewe bestaan in vreugde oor die waarheid, wat beteken vreugde oor God, wat die Waarheid is (10.13). De doctrina Christiana (396-426) soek die waarheid 
van proposisies in die heilige boeke van die kerk. De Trinitate (406-420) bevestig wat reeds bevind is: God is waarheid (3.1) en die waarheid is onsterflik, onverganklik en onveranderlik (4.4).

\section{Samevatting}

"Thus truth - the knowing of it, the accurate communication of it, and the making of it, a standard for the direction of one's will - is an irreducible principle of Augustine's mature thought. It stands for him, together with the principle of love, as one of the two essential parts of a double-matrix ethic" (Carney 1991:29).

Dit is duidelik dat die neo-Platoniese ideëleer 'n groot invloed op Augustinus se denke uitgeoefen het, hoewel hy in sy latere fase sy waarheidsopvatting meer teologies en Christologies ingeklee het. Die Waarheid wat alle waarheid moontlik maak, is onsterflik en onverganklik en is ten diepste identies aan Christus, aan God. Stock (1998:409-410) konkludeer dat Augustinus 'n relasionele waarheidsbeskouing daarop nahou: die waarheid bestaan nie binne of buite die mens nie, maar bestaan tegelyk binne en buite - die waarheid bestaan in relasies. Dis egter 'n ope vraag of Stock nie hiermee 'n moderne probleemstelling in Augustinus terugprojekteer nie.

\subsection{Augustinus oor die leuen}

Augustinus het twee geskrifte oor die leuen die lig laat sien. Die eerste, De Mendacio, is in 394 geskryf kort voordat hy in 395 biskop in Hippo (in die moderne Algerië) geword het. Dit is ' $n$ ingewikkelde en selfs verwarrende geskrif en Augustinus deel in sy Retractationes (1.27) mee dat hy oorweeg het om die boek te skrap, te meer nadat hy 'n tweede boek oor dieselfde tema geskryf het. Tog het hy die boek uiteindelik, maar na hersiening, behou. De Mendacio is waarskynlik geskryf omdat die verskynsel van lieg veel voorgekom het in die streek (Numidië) waar Augustinus gewoon het (Lee 1979:8), en omdat sommige Christene hulle hieroor op die Skrif beroep het.

Sy tweede geskrif, Contra Mendacium, uit die jaar 420 is geskryf na aanleiding van 'n vraag van 'n priester uit Spanje met die naam Consentius. Daar het bepaalde ketterye onder leiding van Priscillianus ontstaan, maar die ketters het hulle uiters ortodoks voorgedoen. Consentius stel nou voor dat die katolieke Christene van die leuen gebruik maak om die Priscilliane te penetreer en te ontmasker. Die Priscilliane het 
immers hulle ketterye met ontkennings, leuens en meineed verbloem. Hierop antwoord Augustinus dat Consentius hom nie oortuig het dat katolieke Christene eweneens van leuens mag gebruik maak nie.

\section{De Mendacio (394)}

Augustinus ondersoek die vraag wat ' $n$ leuen is en skakel onmiddellik die sogenaamde grapleuen uit omdat daarin geen misleiding voorkom nie $(1-2,18)$. Ook iemand wat iets vals beweer, maar glo dis die waarheid, lieg nie (3). Hý is 'n leuenaar wat een ding in sy hart dink, maar 'n ander ding sê, doen of aandui (3). Die fout van iemand wat lieg, is dus geleë in misleiding $(3,5)$. Die leuenaar het 'n wil om te mislei (voluntas fallendi). Die maatstaf vir lieg of nie-lieg is dus nie geleë in uitwendige sake nie maar in die oortuiging van die mens se innerlike. Wie lieg, gee 'n ander voorstelling van sake as waarvan hy in sy hart oortuig is. Waarheid bestaan in 'n ooreenstemming van denke en spreke/doen.

Augustinus stel vervolgens die vraag of dit dan nie soms nuttig is om te lieg nie en dan verwys hy na Sara (Gen 18:15), Jakob (Gen 27:19) en die Egiptiese vroedvroue (Eks 1:19-20). Wat van die vlugteling aan huis en 'n ernstige siek persoon - moet ten opsigte van hulle nie gelieg word nie (5)? Aan die ander kant is daar ook diegene wat van geen leuen wil weet nie en ook hulle beroep hulle op die Skrif, byvoorbeeld Eksodus 20:16, Wysheid 1:11, Psalm 5:6, Matteus 5:37, Efesiërs 4:25 (6). Volgens hierdie interpretasie moet die $\mathrm{Ou}$-Testamentiese voorbeelde van leuens figuurlik en profeties verstaan word $(7,26)$. In die Nuwe Testament is daar geen voorbeelde van sulke leuens nie (8).

Augustinus wys die leuen om 'n vlugteling te beskerm van die hand op grond van Psalm 5:5-6 (9). Die een wat lieg, vermoor sy siel (vir ewig), ter wille van 'n ander se (tydelike) liggaamlike lewe. Niemand twyfel immers daaraan dat "die siel beter is as die liggaam nie" (9). Naasteliefde word ook begrens deur selfliefde (9). Wél mag 'n Christen sy tydelike lewe vir sy naaste se ewige lewe aflê (9). As leuens ten opsigte van 'n vlugteling aanvaarbaar is, dan behoort daar ook ter wille van die naaste gesteel en gehoereer te word (9)! (Dit is uit bogenoemde duidelik dat Augustinus se [neo-]Platoniese mensbeskouing hier 'n bepalende rol speel.) Augustinus is van oordeel dat wie 'n leuen vertel, 'n keuse maak ten gunste van persoonlike of ander se tydelike voordeel bó die waarheid en dit is pervers (11). Indien eenmaal aanvaar word dat leuens vertel mag 
word, hoe gaan ons dan ooit weet wie die waarheid praat (11)? Volgens Augustinus is dit beter as 'n sonde teen jou gepleeg word, as om self te sondig: hoewel moord 'n groter sonde is as om te steel, is dit slegter om self te steel as om vermoor te word (14).

Augustinus is veral uitgesproke daaroor dat daar nooit ten opsigte van godsdienstige sake gelieg mag word nie, want dan word alles twyfelagtig $(17,21)$. 'n Leuen ten koste van iemand se tydelike lewe is reeds verfoeilik, hoeveel te meer ten koste van sy of haar ewige lewe (21). Augustinus wys ook daardie leuens af wat niemand benadeel nie en selfs bevoordeel, soos waar 'n arme van 'n ryke sou steel (20). Dit is sowel sondig om te lieg ten einde 'n persoon se sonde weg te steek as om die sondaar weg te steek (22). Hy verwys hier positief na biskop Firmus van Thagaste wat nóg gelieg nóg verraai het dat hy 'n vlugteling weggesteek het (23). In so 'n geval moet nie gelieg word nie, ook nie niks gesê word nie, maar wel: "Ek weet waar hy is, maar sal die plek nooit aanwys nie" (24). Augustinus gaan vervolgens daartoe oor om agt vorms van leuens op te som en dan nader te bekyk (25) (vgl Mann 1999:155-156):

- 'n Persoon lieg ten opsigte van godsdiens (bv om Christus te verloën). Dit is die hoofleuen.

- ' $\quad$ Persoon lieg, terwyl iemand benadeel en niemand anders bevoordeel word nie.

- $\quad$ 'n Persoon lieg, terwyl iemand (geestelik) benadeel en iemand anders bevoordeel word.

- $\quad$ 'n Persoon lieg bloot vir die plesier van te lieg en te mislei - 'n klinkklare leuen.

- 'n Persoon lieg bloot om kamerade tevrede te stel en 'n gesprek te veraangenaam.

- 'n Persoon lieg sonder om iemand te benadeel, terwyl iemand (ten opsigte van besittings) bevoordeel word (vgl waar 'n arme van 'n ryke steel).

- 'n Persoon lieg sonder om iemand te benadeel, terwyl dit iemand anders (se lewe) bevoordeel (bv' $n$ vlugteling wie se lewe gered word).

- 'n Persoon lieg sonder om iemand te benadeel, terwyl iemand anders van liggaamlike verontreiniging (verkragting, homoseksualiteit) gevrywaar word.

Augustinus verwerp vorms 1 tot 5 sonder meer. (Dit is nogal verrassend dat hy ook vorm 5 (skertsleuen) afwys, aangesien hy dit vroeër aanvaar het, moontlik omdat hy 
hier 'n onderskeiding tussen ware en onware skerts op die oog gehad het [vgl Lee 1979:64].) Ook vorms 6 en 7 wys hy af, hoewel hy daarop attendeer dat in hierdie gevalle daar meningsverskil bestaan. Hy verwerp ook vorm 8 , omdat reinheid van die siel belangriker is as kuisheid van die liggaam. Daar is egter 'n duidelike gradasie in die sonde in die verskillende vorme; ' $n$ verswaring van die sonde tree in vanaf vorm 8 tot 1 (42).

Vervolgens word die Skrifgegewens weer nagegaan. Die Ou-Testamentiese materiaal word deur middel van allegoriese verklaring (wat hy van Ambrosius in Milaan geleer het) wegverklaar (1 Kor 10:1-11) - die aksent val vir hom klaarblyklik op die Nuwe-Testamentiese gegewens (26). Wat reeds in die woorde (verba) van die Skrif duidelik is, word nog duideliker in die lewe (exempla) van die heiliges (30) - hoewel hy die exempla van die Ou-Testamentiese heiliges wat van van leuens gebruik gemaak het, uitskakel of wegverklaar (Lee 1979:31, 35). Na paragraaf 34 begin die argumentasie ietwat uitrafel. Augustinus wys nog op drie sake wat vir 'n heilige lewe nodig is: pudicitia corporis, castitas animi, et veritas doctrinae (40). Liefde tot God en die naaste is onmisbaar. Die Skrifgegewens dui daarop dat ons nooit leuens mag vertel nie (42).

\section{Contra Mendacium (420)}

Ons het reeds daarop gewys dat Augustinus in hierdie geskrif die vraag van Consentius beantwoord, naamlik of katolieke Christene ook van leuens mag gebruik maak ten einde die ketterye van die Priscilliane binne te dring en te weerlê. Die Priscilliane het beweer dat die waarheid in die hart bewaar kan word, maar dat om leuens aan vreemdelinge voor te hou, geen sonde is nie (2). Hierop gee Augustinus 'n duidelike afwysende antwoord. Augustinus vra wat van Romeine 3:7-8 word, indien die standpunt van die Priscilliane aanvaar word. Daarby vernietig hulle alle martelaarskap, want dan moes martelare eerder gelieg as bely het (3). Die Priscillane verwys na die voorbeeld van Jehu (2 Kon 10:18ev), maar Augustinus merk op dat dit 'n slegte voorbeeld is (2 Kon10:31) (3). Daar is baie soorte leuens, sê hy, maar almal moet gehaat word; daar is geen leuen wat nie teen die waarheid is nie (4).

Augustinus merk op dat dit gevaarliker vir katolieke is om te lieg ten einde ketters uit vang, as wat dit vir ketters is om te lieg sodat hulle nie deur katolieke ontdek mag 
word nie (4). Stel jou voor dat 'n katoliek al die ketterye van die Priscilliane moet aanprys (5)! Hy vra: as katolieke begin lieg, hoe sal die Priscilliane hulle ooit kan glo? Kan enigiemand oorreed word om te glo dat iemand nie lieg om nie uitgevang te word nie, maar wel lieg om uit te vang (7)?

Die Priscilliane beweer dat die siel deel van God en van dieselfde substansie as God is - 'n godslasterlike gedagte - en nou word van katolieke verwag om dieselfde te sê: die Priscilliane gaan in teen die scientia; die katolieke teen die conscientia (8). Wat is nou die ergste, vra Augustinus: hy wat iemand onwetend mislei, of hy wat God welwetend belaster (8)? Wie verloën, sal deur Christus verloën word (Matt 10:33) (10). Christus het ook nêrens gesê dat sy skape wolfsklere moet aantrek tussen die wolwe nie (Matt 10:16) (12). Dis sonde om met die hart te glo en met die mond te lieg (Rom 10:10) - soos wat Petrus gedoen het (13). Om die waarheid in die hart te spreek (Ps 15:2), moet opgevolg word om die waarheid met die mond te spreek (Ef 4:25) $(14,15)$. Dis wel moontlik dat Christus met verborge motiewe gepreek word (Fil 1:18), maar nie nadat Hy eers verloën is nie (16)!

Gestel nou, redeneer Augustinus, 'n Priscilliaanse vrou sou vir 'n katolieke man sê: kom slaap by my en ek vertel jou al ons geheime, is dit dan aanvaarbaar (17)? Volgens Augustinus maak dit 'n groot verskil om watter rede, vir watter doel en met watter intensie iets gedoen word; sondige dade kan nooit op grond van rede, doel of intensie goed word nie (18). Augustinus wys 'n doel-heilig-die-middel etiek summier af. Ons mag byvoorbeeld nie van die rykes steel om aan die armes te gee nie (18). Augustinus hanteer wel die onderskeiding doodsondes en vergeeflike sondes (peccata mortalia, peccata venialia) maar hy ag beide verkeerd (19). Wie uit begeerte of gierigheid steel, is slegter as wie uit jammerte of barmhartigheid steel (19).

Wat dan van peccata compensativa, dit wil sê sonde wat ter wille van 'n goeie saak gedoen word, byvoorbeeld Lot wat sy dogters vir die Sodomiete (vir owerspel) aanbiec om sy gaste te beskerm (Gen 19) (20)? Augustinus wys die gedagte af dat 'n kleiner sonde gedoen mag word ten einde 'n groter sonde te voorkom - so 'n standpunt vorm 'n glybaan na al groter sonde $(20,21,30)$. Lot se optrede, gebore uit vrees, keur hy af, en ook Dawid s'n wat gebore is uit wraak (1 Sam 25); daar behoort in die Skrif duidelik te onderskei te word tussen wat gedoen is en wat gedoen behoort te word, tussen 
voorbeeld en voorskrif (21). Alle Bybelse voorbeelde is nie noodwendig morele voorskrifte nie (22).

$\mathrm{Al}$ is dit so dat elkeen wat lieg, die waarheid verberg, is dit ook waar dat nie elkeen wat die waarheid verberg, lieg nie, byvoorbeeld Abraham ten opsigte van Sara (Gen 20,23). Ook in die geval van Jakob (Gen 27) het ons nie met 'n leuen te doen nie, omdat die gedeelte metafories verstaan moet word (24).

Hoe moet die verfoeilike sekte van die Priscilliane dan hanteer word? Augustinus antwoord soos voig:

- Toon aan dat wat die Priscilliane as leuens in die Skrif aansien, nie leuens is nie.

- Toon aan dat, indien dit wel leuens is, dit nie navolging verdien nie.

- Nooit mag daar egter in die geval van godsdienstige leerstellings gelieg word nie (25). Die Priscilliane het byvoorbeeld geleer dat ' $n$ mens Christus mag verloën om midde van vyande nog 'n Christen te kan wees.

Augustinus gee besondere aandag aan die Skrifgegewens en wel vanuit sy definisie dat ' $n$ leuen 'n valse aanduiding is met die wil om te mislei (26). Die Ou-Testamentiese gegewens moet figuurlik verstaan word en in die Nuwe Testament is daar geen sodanige voorbeeld nie (26). Ook in die geval van Christus (Luk 8:45; 24:28; Joh 11:34) is dit slegs oënskynlike leuens $(27,28)$. Die Ou Testament bevat 'n weergawe van sowel slegte as goeie dade, verwerplike as navolgenswaardige dade (29). Augustinus (30) vra: waarom volg die Priscilliane byvoorbeeld Tamar se leuen na, maar nie Juda se owerspel nie (Gen.38)?

Volgens Augustinus kan daar geen wettige leuen wees nie, want die wet is waarheid (Ps 119:42) en geen leuen is in die waarheid nie (1 Joh 2:21, 31, 37). Dit is waar dat sommige sondes groot en sommige klein is - die Stoïsyne sê almal is gelyk - maar dit is verkeerd om te sê dat sommige sondes verkeerd en ander reg is (31). Godslastering is slegter as vals sweer, want by laasgenoemde word God ingeroep as getuie by 'n valse saak, maar by eersgenoemde word valse dinge van God gesê (39). Wat in die optrede van die vroedvroue (Eks 1) en Ragab (Jos 2) beloon was, was nie hulle misleiding en leuens nie, maar hulle welwillendheid en goedheid (32). Burgers van die hemelse stad 
mag nooit lieg nie (33). Ragab se daad is prysenswaardig, maar haar leuen afkeurenswaardig (34).

Moet aan 'n ernstige siek vader vertel word dat sy seun dood is?, vra Augustinus. Om "nee" te sê, of "ek weet nie", is albei leuens (36). Dit is absurd en onsinnig om te sê dat die waarheid ons leer om te lieg (38). Augustinus bespreek ook die vraag of iemand wat in die mag van boosdoeners beland het, hulle mag belieg of bedrieg ten einde sy doopgeleentheid te kan bywoon - 'n vraag wat hy weereens negatief beantwoord (40, 41). Só moet die Priscilliane benader en beantwoord word, nié deur een van hulle te word nie, ook nie deur self leuenaars te word om leuenaars uit te snuffel nie(41).

\section{Samevatting}

- Hoewel daar by Augustinus nie 'n eenvoudige definisie gevind word nie, kan tog samevattend gesê word dat om 'n leuen te vertel, volgens hom beteken om een ding te dink en ' $n$ ander ding te sê, om te mislei. Leuen beteken tweespalt tussen denke en spreke, soms ook tussen denke en syn. Die aksent kan val op die wil om iets onwaars mee te deel (voluntas falsum enuntiandi), of op die wil om te bedrieg (voluntas fallendi) (Lee 1979:58). In boek 18 van sy Enchiridion (421-423) herhaal Augustinus hierdie gedagtes.

- Augustinus wys alle leuens af, veral omdat dit teen God, wat die Waarheid is, ingaan én omdat dit vir die (eie) siel verderflik is (vgl Rist 1999:192-193). Hy verdedig die Sokratiese standpunt dat dit beter is om kwaad te ondergaan as om dit te doen, maar hy gaan selfs verder en voer aan dat dit ook beter is dat iemand anders sal ly as dat ek kwaad sal doen.

- Met die moontlike uitsondering van skertsleuen, wys hy alle vorme van leuens af. Hy aanvaar wel gradasie in die leuenpraktyk, groter en kleiner leuens, met godsdienstige leuens as die grootste, maar alle leuens bly verkeerd en sondig.

- Dit is uit sy behandeling duidelik dat Augustinus die Skrif as norma normans hanteer - inklusief die Ou-Testamentiese apokriewe (wat in sy tyd deel van die kanon was). Sy hermeneutiese prinsipes en allegoriese eksegese maak dit vir hom maklik om die gevalle waarvan leuens in die Ou Testament sprake is, weg te verklaar. Baie sinvol is sy onderskeiding tussen voorbeeld en voorskrif - alhoewel dit nie alle vrae ondervang nie. 
- Dit is duidelik dat sy (neo-)Platoniese mensbeeld hier 'n bepalende rol speel. "Die siel is beter as die liggaam", daarom is sondes teen die siel gevaarliker as sondes teen die liggaam.

- Augustinus se (Griekse) waarheidsbeskouing (ooreenstemming van denke en spreke, denke en syn) is die vooronderstelling waarvolgens hy die leuenpraktyk wat veral in die Ou Testament voorkom, beoordeel. 'n Ander waarheidsopvatting sal waarskynlik tot 'n ander verstaan van die Ou-Testamentiese gegewens lei.

- Dit val op dat, terwyl Augustinus absoluut geen uitsondering ten opsigte van die leuen toelaat nie, hy wel ten opsigte van "homicide" uitsonderings billik (bv doodstraf, oorlog) (Kirwan 1999:193). Dan is daar ook nog die voorbeeld van die Antiogeense vrou - wat deur Augustinus nie veroordeel word nie - wat met goedkeuring van haar man met 'n hoë offisier geslaap het ten einde haar man van 'n onregverdige gevangenskap te bevry (Rist 1999:196-197, 251).

\section{NA-AUGUSTINIAANSE ONTWIKKELING}

\subsection{Inleiding}

Uit die teologiegeskiedenis is dit duidelik dat die beskouing van Augustinus tot in die Middeleeue en selfs later nagevolg is, deur sowel Rooms-Katolieke as Gereformeerde teoloë (vgl Voetius; Amesius \& Lee, 1979:57-78). Hoewel die agt vorms van leuens nie geyk is nie, was daar by Thomas van Aquino duidelike aansluiting en verfyning (Lee 1979:62-66, 71-78). Ook Thomas onderskei tussen mendacium officiosum (noodleuen), mendacium iocosum (skertsleuen) en mendacium perniciosum (skadeleuen). Thomas wys ook op uitweë soos dissimulatio (dubbelsinnige woorde met die oog op misleiding) en simulatio (dubbelsinnige gebare met die oog op misleiding). 'n Metode wat ook ter sprake kom, is restrictio mentalis (onvolledige woorde met die oog op misleiding) asook die vraag na die rég op waarheid. Thomas sit ook die Griekse waarheidsbegrip voort, hoewel hy daarin verandering aanbring (Vrielink 1956:17-20, 23ev). Waarheid word nie 
net in die ewige dinge gevind nie, maar ook in die geskapene. Die geskapene is waar vir sover dit ooreenkom met die bestemming wat God daaraan gegee het. ${ }^{3}$

Calvyn staan baie skepties teenoor die noodleuen. In sy kommentaar op Josua keur hy die noodleuen (van Ragab) af; dit is nooit wettig om te lieg nie, want wat teen die aard van God ingaan, kan nie reg wees nie (Calvyn 1949:45-48). Tog was Ragab se daad nie ondeugdelik nie, al was dit nie vlekkeloos nie. In sy preek oor die Negende Gebod beklemtoon hy die betekenis van waarheid praat (Calvyn s a:174-188). Die naaste moet sover moontlik beskerm word, maar wanneer dit nodig en goed is en dit van ons gevorder word, moet ons bereid wees om sondes van die naaste (moord, diefstal, korrupsie, oneerlikheid) bekend te maak (Calvyn s a:180).

Klaarblyklik het Luther milder as Calvyn oor die noodleuen geoordeel (Smedes 1983:54-56). Luther het geen waarheidsteorie ontwikkel nie; waarheid was vir hom nie iets abstrak nie, maar die heilsdaad deur die Goddelike Woord voltrek wat die mens dan in geloof aanneem (Möller 1971:54). Die vraag ontstaan hoe etici in latere ontwikkelings die vraagstelling (van veral die noodleuen) benader en probeer beantwoord het.

\subsection{Die leuen as noodleuen}

Die Gereformeerde tradisie verwerp oor die algemeen die gedagte van 'n noodleuen (Geesink 1931:439, 443) en dink eerder in die rigting van óf 'n verberging óf verswyging van die waarheid (Geesink 1931:441, 443). Hierteenoor is veral in die vrygemaak-gereformeerde denke in Nederland ' $n$ ander rigting opgegaan soos duidelik te sien is in die geskrifte van veral Holwerda en Douma. Wie van oordeel is, sê Holwerda (1975:660), dat die negende gebod bedoel dat 'n mens altyd en in alle omstandighede presies die waarheid sal vertel en dat jy nooit mag lieg nie, het die letter losgemaak van die bedoeling en het daarmee die negende gebod losgelaat. Die groot vraag is vir hom nie "of we de feiten niet tekort doen, maar of we de naaste niet tekort doen" (Holwerda 1975:662). Desnoods mag 'n onjuiste verklaring gedoen word. "Als het moet, offer ik de feiten op aan de naaste" (Holwerda 1975:663).

\footnotetext{
3 Vennix (1998) behandel Thomas se waarheidsbeskouing aan die hand van (1) waarheid as analoë term, (2) waarheid as transendentale nosie, (3) waarheid as relasionele relasie en (4) waarheid as maatverhouding.
} 
Ook Douma (1987:113-120; 1997:133) aanvaar die noodleuen, maar dan vir benarde en nie vir lastige situasies nie. "De noodleugen moeten we niet veroordelen. We hebben te maken met een grenssituatie, zoals die zich ook bij andere geboden kan voordoen" (Douma 1987:117). Voorbeelde van sulke benarde situasies is onder andere wanneer die kans groot is dat iemand sal selfmoord pleeg indien die waarheid oor sy of haar mediese toestand meegedeel word, of noodleuens in verband met wegkruipers soos tydens die Tweede Wêreldoorlog (Douma 1997:133). Die Koreaan, Lee, wat onder Douma gepromoveer het, sit hierdie denklyn voort. Op grond van 'n studie van veral die geskiedenis van Ragab (Jos 2), kom Lee (1979:80-91) tot die konklusie dat die (noodsaaklike) noodleuen eties aanvaarbaar is. Die Heilige Skrif wys die optrede van Ragab immers nêrens af nie, trouens, prys dit eerder aan (Heb 11:31; Jak 2:25). Ragab se leuen maak haar nog nie leuenagtig nie (Lee 1979:90). Dieselfde geld ook vir die Egiptiese vroedvroue (Eks 1:15ev), die vrou van Bahurim (2 Sam 17:19ev), Ehud en Jael (Rig $3: 15 \mathrm{ev} ; 4: 18 ; 5: 24 \mathrm{ev})$. Hierdie standpunt word volgens Lee ook nie deur die negende gebod weerspreek nie.

Lee (1979:107-109) verskil dus van Augustiuns wat elke vorm van leuen afwys; hy is van oordeel dat Augustinus se allegoriese eksegese hom parte speel, dat hy ' $\mathrm{n}$ foutiewe vooronderstelling hanteer en dat hy met 'n abstrakte etiese prinsipe werk. Lee (1979:120) gee wel toe dat sy eie onderskeiding nie waterdig is nie: Ragab mislei immers haar eie volksgenote en vernietig so die veiligheid van Jerigo. Opsommend kom Lee (1979:111-154) tot die volgende konklusies:

- Die noodleuen, om onsself of iemand anders uit 'n benarde situasie te red, is moreel aanvaarbaar (Lee 1979:121-126, 149). Die noodleuen mag egter nooit 'n "roetine-saak" word nie en geld slegs vir "grenssituasies" (Lee 1979:121). Dit is 'n uitsonderlike maatreël in 'n uitsonderlike situasie. Dit beteken nie die aanvaarding van 'n doel-heilig-die-middel etiek nie, maar wel dat 'n noodsaaklike doel 'n noodsaaklike middel heilig (soos by Brunner \& Lee 1979:125). Hoewel in oorlogstyd nie alle sedelike bande verval nie, kan ook daar grenssituasies ontstaan waar lieg en bedrieg onvermydelik is (Lee 1979:138-139, 147). 
- Die skertsleuen is geen vorm van leuen (doelbewuste misleiding) nie.

- Geen skuldbelydenis is nodig in die geval van noodleuen nie (soos Thielicke wil) (Lee 1979:141-147). Daar bestaan immers nooit 'n botsing van pligte nie: God vra nooit tegelykertyd twee teenstrydige sake nie.

- Die noodleuen mag nooit ten opsigte van godsdienstige sake gebruik word nie (Lee 1979:153).

Die standpunt van Lee roep egter die volgende vrae na vore: (1) Mag daar ter wille van die bevordering van die koninkryk van God gelieg word? Vergelyk die probleem rondom Ragab. (2) Waarom tipeer die Skrif nêrens die woorde van Ragab as leuen nie? Speel die Griekse waarheidsteorie nie vir Lee parte nie? (3) Is dit werklik so eenvoudig dat daar eties gesproke nooit van 'n botsing van pligte sprake kan wees nie (vgl Buys 1976).

Redelik onlangs het Smedes (1983:224-237) uitgebreid oor die noodleuen besin (vgl ook Thielicke 1965:122-189). Hy onderskei vyf soorte leuens. Hy wys daarop dat die skadelose leuen (witleuen) nie altyd so skadeloos is nie, hoewel dit soms nodig mag wees (Smedes 1983:225-227). Ook teen die welwillendsheidsleuen kan kritiek ingebring word, hoewel ook hier uitsonderings onvermydelik is (Smedes 1983:227-232). Leuens aan slegte mense (aan Hitler bv) mag soms nodig wees (Smedes 1983:232-233). Leuens ter wille van lewensbehoud (bv aan die Gestapo) is soms ook nodig (Smedes 1983:233234). Ook swygleuens (bv in huwelikskonteks) is moontlik (Smedes 1983:234-237). Smedes (1983:220-221) se denklyn is gerig teen 'n absolutistiese benadering (Augustinus, Thomas, Calvyn, Kant) en maak dus voorsiening vir die kategorie van uitsondering.

\subsection{Die leuen as noodwaarheid of krisiswaarheid}

'n Aantal navorsers soek die oplossing in 'n ander rigting en praat eerder van 'n noodwaarheid of krisiswaarheid as van 'n noodleuen. Volgens Volten (s a:142) "moet er wel eens 'gelogen' worden om de leugen te vernietigen." Die negende gebod eis drieërlei trou: aan onsself, aan God en aan die naaste. Daarom is dit geen noodleuen om in oorlogstyd aan die vyand te sê dat jou seun nie tuis is nie, terwyl jy hom in die kelder weggesteek het; dit is veeleer 'n "noodwaarheid" (Volten s a:165). Ook Smelik (1967: 169) praat van die gebruikmaking van onjuistheid in diens van die waarheid. 
Heyns (1970:233) onderskei tussen noodleuen (wat hy afwys) en krisiswaarheid (nie die volle waarheid nie), wat hy aanvaar, byvoorbeeld in die geval van Ragab. Volgens Heyns (1970:235) gaan dit "nooit nét om die blote mededeling van korrekte feite nie, maar gaan dit ook om die vraag na die besondere verband waarbinne en omstandighede waaronder en persoon aan wie en dus wyse waarop dit meegedeel word." Sy aansluiting by Bonhoeffer in hierdie verband is opvallend (Heyns 1970:233, 236). In sy sosiale etiek leun Heyns sterk aan teen die Griekse waarheidsbeskouing as hy waarheid omskryf as "betroubare uitspreek van die werklikheid" (Heyns 1986:119; vgl hierteenoor 1970:232). Waarheid word deur hom egter sterk aan die liefde verbind (Heyns 1986: 117).

Die Duitse etikus Bonhoeffer distansieer hom van Kant se kontekslose en universele waarheidsbeskouing. Volgens Bonhoeffer (1966:385-394) word die waarheid kontekstueel bepaal. Die waarheid as ooreenstemming tussen denke en spreke is heeltemal ontoereikend. Dink aan 'n skoolkind wat weier om op 'n vraag van die onderwyser te erken dat sy vader beskonke tuis gekom het. Ongetwyfeld het hierdie insigte van Bonhoeffer groot invloed gehad, soos ook blyk uit die aansluiting daarby deur Lochman (1979:137-141), vir wie die konteks en die naaste (medemenslikheid), genade en liefde medepalende faktore is by waarheidsuitsprake.

Dit is egter 'n ope vraag of daar inderdaad 'n wesenlike verskil is in die twee benaderings van die noodleuen en noodwaarheid/krisiswaarheid en of dit nie net verskillende woorde is vir dieselfde saak nie. Vervolgens word ondersoek ingestel na enkele waarheidsteorieë.

\section{WAT IS WAARHEID? 'N ONDERSOEK}

Augustinus het ons denke oor die waarheidsvraag gestimuleer en daarom is dit nodig om na enkele belangrike waarheidsteorieë te gaan kyk ten einde 'n moontlike oplossing te formuleer (vgl Eisler 1910:1702-1723; Möller 1971:11-133; Müller 1989).

\subsection{Relativistiese waarheidsteorie (die waarheid bestaan nie en is onvindbaar)}

Volgens hierdie teorie bestaan daar nie so iets soos objektiewe kennis en waarheid nie en word ware wysheid net gevind in 'n houding van onthouding van oordeeluitsprake en 'n 
onverskillige houding ten opsigte van uiterlike dinge. Geluksaligheid bestaan in 'n houding van apatie. Wat in hierdie teorie waardeer kan word, is die aksent op die voorlopigheid van alle menslike kennis (kenteoretiese voorlopigheid), maar om vanuit die voorlopigheid van kennis (en waarheid) tot die onmoontlikheid daarvan te konludeer, is (reeds) kenteories onhoudbaar. Ons het daarop gewys dat Augustinus hierdie vorm van skeptisisme aan grondige kritiek onderwerp het.

\subsection{Korrespondensieteorie (ooreenstemming van denke en syn)}

Volgens die korrespondensieteorie is ' $n$ bewering waar indien die bewering korrespondeer/(ooreenstem) met die werklikheid, dit wil sê 'n ooreenstemming tussen denke en syn (adaequatio intellectus et rei) (Brümmer 1975:166-168, 176-177; Loonstra 1994: 150-151). Die ware syn is vir ons sintuie verborge sodat ons sintuiglike waarneming ons geen betroubare kennis verskaf nie. Die ware kennis is voorbehou vir die denke (nous) van die mens. Die denke ken die waarheid, wat onveranderlik en ewig is. So gesien, is waarheid die selfonthulling van die syn aan die denke van die mens. Waarheid het te doen met die ware en werklike stand van sake (Bultmann 1965:238-241; vgl Pop 1957:234-235; Koch 1965:55-58).

Die waarheidselement hiervan is dat dit belangrik is om die waarheid van 'n bewering in verband te bring met die verhouding tussen bewering en werklikheid (stand van sake), maar dit is eensydig om die waarheid van 'n bewering (bloot) te sien as ooreenstemming tussen ongelyksoortige groothede, naamlik bewering en feit ( $\mathrm{vgl}$ Vrielink 1956:13-16). Volledige korrespondensie tussen weergawe en gebeure is bowendien nie haalbaar nie. In die Skrif is daar inderdaad voorbeelde waar die teenstrydigheid tussen woord en feit as 'n leuen aangegee word (Lee 1979:114-115), byvoorbeeld Deuteronomium 13:14; 22:20ev; Rigters 16:13; 1 Konings 10:6ev; Handelinge 5:8; die negende gebod.

\subsection{Koherensieteorie (ooreenstemming van denke en denke)}

Volgens hierdie teorie is ' $n$ bewering waar wanneer dit koherent is (= geïmpliseer word deur en nie in stryd is nie) met alle ander bewerings (Brümmer 1975:169-171, 177). Hier gaan dit dus nie oor korrespondensie tussen bewering en feit nie, maar oor korres- 
pondensie tussen bewering en bewering. Natuurlik is daar 'n waarheidselement as beweer word dat bewerings/versekerings mekaar nie mag weerspreek nie, maar die probleem is: hoe weet ons dat alle ander bewerings waar is?

\subsection{Pragmatiese teorie (die waarheid moet werk)}

Hiervolgens is ' $n$ bewering waar indien dit koherent is met 'n konseptuele skema en laasgenoemde is waar indien dit wérk (Brümmer 1975:171-173, 177-178). In die uitwerking van hierdie teorie het drie nuanses ontwikkel: terwyl Peirce geoordeel het dat die maatstaf vir werkbaarheid geleë is in die gangbare wetenskaplike mening, was James van mening dat dit geleë is in die lewensbeskouing en daaglikse lewe van die individu; terwyl Dewey dit weer gesoek het in planne wat probleme oplos.

'n Unieke vormgewing van waarheid as praksis word in die Marxisme aangetref (Möller 1971:77-78). Religie en idealistiese fillosofie (Hegel) moet volgens Marx afgelê word aangesien dit die mens vervreem. Die waarheid van die "anderkant" moet vervang word met die waarheid van die "duskant". Die teoretiese waarheid moet vervang word met die praktiese waarheid. "Wahrheit wird zur Praxis, weil sie sich nur als Praxis vollziehen kann" (Möller 1971:78). In hierdie verband speel menslike arbeid, as waarheid van die menslike daad, 'n besondere rol.

Die waarde van hierdie benaderings lê daarin dat dit aanvoer dat bewerings ook praktiese en praktykveranderende waarde behoort te hê. Die probleem is egter dat dit die waarheid net sien in terme van praktiese oorwegings, dat dit waarheid en nuttigheid identifiseer en so die waarheid relativeer.

\subsection{Emotiewe teorie (waarheidsuitsprake is sinloos)}

Volgens die emotiewe teorie van Ayer is uitsprake oor waarheid (asook oor skoonheid en goedheid) emotiewe uitsprake, voeg niks by tot 'n feitlike konstatering nie en is dus oorbodig. Hierdie teorie herinner sterk aan die standpunt van die moderne skeptisisme waar beweer word dat objektiewe waarhede in die etiek onsinnig en verdag is omdat dit uitgedruk word in proposisies van 'n ander logiese struktuur as byvoorbeeld in die fisika (waar daar wel objektiewe waarhede sou bestaan). Die emotiewe teorie fouteer egter 
daarin dat 'n waarheidsuitspraak 'n evaluatiewe en nie 'n deskriptiewe uitspraak is nie (Brümmer 1975:175-176).

\subsection{Relasionele teorie (waarheid ontstaan in die relasie van subjek en objek)}

Die relasionele waarheidsteorie probeer sowel die gevare van 'n objektiewe as subjektiewe waarheidsbegrip oorkom deur uit te gaan van 'n wisselwerking tussen die waargenome objek en die waarnemende subjek. Die waarheid is nie te vind in óf die objek óf die subjek nie maar in die onlosmaaklike wisselwerking tussen beide (GKN 1980:5-14; vgl Van Huyssteen 1986:163, 209). Die geloofwaardigheid van die Bybel staan dus nie vooraf vas nie, maar is 'n gebeure wat voltrek word in die omgang met die Bybel. Die waarheid word nie subjektief uit die mens ontwerp nie, ook nie objektief deur God aangereik nie, maar kom relasioneel tot stand (vgl Loonstra 1994:180-182).

Die relasionele waarheidsteorie vertoon 'n opvallende ooreenkoms met Brunner se gedagte van "Wahrheit als Begegnung". Brunner (1963:110) wend 'n poging aan om die problematiek van objektivisme (Katolisisme en ortodoksie) en subjektivisme (Piëtisme, eksistensialisme) met sy beskouing van waarheid as ontmoeting te oorwin. Om te glo, beteken byvoorbeeld nie om aan "iets" (iets waar, 'n leerstelling) te glo nie, "sondern personhafte Begegnung, Vertrauen, Gehorsam und Liebe". Brunner (1963:134) gee egter toe dat hierdie geloofsverstaan met "Wahrheit als Lehre" verbonde is.

Die standpunt van "waarheid as ontmoeting" speel ook in die Hervormde teologie in Suid-Afrika (voortaan HTSA) 'n belangrike rol, trouens Loader (1996:584) deel mee dat die boek van Brunner lank 'n voorgeskrewe handboek vir Hervormde teologiese studente was. Indien die teologiese posisie van die NHKA as "Bybels-Reformatories" getipeer kan word (Oberholzer 1993:880), dan, so oordeel Loader (1996:585), is die Etiese Teologie met die beskouing van "waarheid as ontmoeting" en "die waarheid is eties", 'n "egte verskyningsvorm" van die Bybels-Reformatoriese teologie (vgl Loader 1988:42-55). Loader is op soek na 'n derde opsie wég van 'n ortodoks-gereformeerde en liberaal-modernistiese model, wat hy dan in die Etiese Teologie meen te vind. Beide konfessionalisme en modernisme (positivisme) werk met 'n proposisionele waarheidsbeskouing (Loader 1996:573, 576). Die Etiese Teologie daarenteen, verwerp die proposisionele waarheidsbeskouing waarvolgens die waarheid in proposisies (as geobjektiveerde waarheid) vasgevang kan word en werk met 'n ander waarheidsbeskouing. Ten einde die 
gevaar van subjektivisme te vermy, aanvaar die Etiese Teologie die Bybel as die objektiewe kant van die Goddelike selfbekendmaking asook die kerklike kant van die openbaring (Loader 1996:580-581). Die vraag ontstaan egter of die uitspraak "die waarheid is eties" en die "waarheid as ontmoeting" nie self 'n proposisie en 'n stuk geobjektiveerde waarheid is nie. Die verdere vraag waar hierdie nonproposisionele waarheidsbeskouing sy oorsprong het, kan ook nie vermy word nie. Nee, antwoord Loader (1996:581), proposisies bly nodig, selfs "onontbeerlik", maar hulle mag nie verselfstandig word nie. Volgens Loader is die HTSA diepgaande deur die Etiese Teologie beïnvloed en lê die Dialektiese Teologie (wat ook die HTSA beïnvloed het) in die verlengde van die Etiese Teologie (Loader 1996: 582, 583).

Hiervan verskil D J C van Wyk (snr). Hy stem wel saam met die waarheidsbeskouing van waarheid as ontmoeting: "dis deel van ons teologie" (Van Wyk 1998:253; 1999:121), maar hy verwerp die gedagte dat die Dialektiese Teologie in die verlengde van die Etiese Teologie lê (1998:253) ${ }^{4}$; die Etiese Teologie beskou hy as "wesensvreemd" aan die HTSA met "geen invloed" daarop nie (Van Wyk 1998:261; 1999:148149). Die Etiese Teologie is te nonkerklik en te sinteties in sy benadering (Van Wyk 1998:257-258; 1999:149). Van Wyk (1998:247, 251) is van mening dat die konfessionele rigting - as vierde opsie - 'n veel groter invloed op die HTSA as die Etiese Teologie gehad het en self kies hy daarom vir die Bybels-Reformatoriese lyn van Kohlbrugge, Hoedemaker en Barth (Van Wyk 1999:149). ${ }^{5}$

Dit val ook op dat die Nederlandse sinodale rapport, God met ons (GKN 1980), deur die HTSA verskillend beordeel is. Terwyl Geyser en Veldhuysen dit aangeprys het, is dit deur B Engelbrecht skerp gekritiseer (verwysings by Van Wyk 1989:25). Klaarblyklik heers daar binne die HTSA nie eenstemmigheid oor die relasionele waarheidsbegrip nie. ${ }^{6}$

\footnotetext{
${ }^{4}$ Loonstra (1994:95) oordeel dat die Skrifbeskouing van Barth dig in die buurt van die etiese teoloè kom.

5 Dit is besonder interessant om daarop te let dat die HTSA hom hewig verset teen ' $n$ positivistiese teologie maar tog sterk aansluiting vind by die teologie van Karl Barth, en dit terwyl juis Barth van "Offenbarungspositivismus" beskuldig word (Bonhoeffer 1970:306, 312, 359).

${ }^{6}$ Hierdie bevinding is onlangs bevestig deur die volgende opmerking van $\mathrm{P} M$ Venter in ' $\mathrm{n}$ artikel in HTS 55(2\&3), 1999:620: "Dit is tot op hede geen uitgemaakte saak of die etiese rigting of die konfessionele rigting die kenmerk is van die Hervormde teologie nie".
} 
Teen die standpunt van Brunner kan daar, benewens waardering vir sy verset teen 'n rasionalisties-objektivistiese waarheidsbeskouing, tog bepaalde kritiek ingebring word (vgl Vrielink 1956:120-124). Wat by Brunner ontbreek of onderbelig word, is (1) die feit dat God nie net relasie skep nie maar in God se trou (emet) ook handhaaf. Brunner se gebrek aan grondige eksegese speel hom hier parte. (2) Brunner onderbelig die plek van Christus in sy waarheidsopvatting; Christus is nie net die weg tot waarheid nie, maar ook die wese daarvan. (3) Brunner onderspeel die plek en betekenis van die Christelike (objektiewe) leerwaarheid - wat wel tog 'n onmisbare komponent van die Bybelse waarheidsbeskouing is. Begegnungswahrheit en Vernunftwahrheit dreig voortdurend om uit mekaar te val (Szekeres 1970:64).

Teen die relasionele waarheidsteorie word ook aangevoer dat dit die perspicuitas van die Skrif in gedrang bring en die geloofsaspek ten koste van die openbaringsaspek beklemtoon. ' $n$ Mens kan nie tegelyk produsent en produk van die waarheid wees nie. Is dit verantwoord van die relasionele hermeneutiek om sowel ons denke as kenne asook die waarheid te historiseer (Loonstra 1994:186)?

\subsection{Kontekstuele teorie (die waarheid word kontekstueel gekonstitueer)}

Die kontekstuele waarheidsteorie is veral terug te vind by die sogenaamde Bevrydingsteologie (Loonstra 1994:183-184). Hierdie teologie kom in verset teen 'n objektiverende, abstraherende en teoretiserende denke wat van ewige waarhede uitgaan sonder dat dit die konkrete werklikheid raak of verander. Nie die historiese konteks van die Ou- en NuweTestamentiese Bybelskrywers is die vertrekpunt vir die verstaan van die Bybelse waarheid nie, maar wel die kulturele, sosiale en politieke konteks van die (veral gemarginaliseerde) mens. Alle teorie (ook van die sogenaamde westerse ortodokse teologie) word immers voorafgegaan deur praktiese belange. Wat belangrik is, is ' $n$ sosiale interpretasie ten einde by te dra tot sosiale transformasie (West 1991:22, 60; vgl Maimela 1988:321-334).

Dit is belangrik om in die vraag na waarheid die konteks te verreken, maar daarmee is nog nie gesê dat die konteks die waarheid konstitueer nie - soos in die kontekstualisme gebeur. Die waarheid is wel kontekstueel, maar nog nie kontekstualisties nie. Waarheid kom nie bloot uit die konteks óp nie maar kom veral daarop áf - 
anders word 'n subjektivistiese waarheidsbegrip onvermydelik. Dat die waarheid egter vrý maak, ook sosiaal en struktureel vry, kan egter onmoontlik ontken word. Maar dis 'n vryheid groter en meer as net sosiale vryheid (vgl Loonstra 1994:189-190).

\section{WAT IS DIE WAARHEID}

Vervolgens word 'n poging aangewend om 'n sintese te bewerk van die materiaal wat tot dusver aan die orde gestel is. Die verskillende aspekte wat genoem word, behoort nie los van mekaar hanteer te word nie, maar as 'n eenheid.

\subsection{Die waarheid is "persoonlik"}

Word die Bybelse waarheidsbeskouing ondersoek, blyk dat dit - en wel in tweërlei opsig - sterk persoonsgerig is. Anders as die Griekse waarheidsbegrip, wat sterk rasioneel ingeklee is, is die Bybelse denke veel meer personeel.

Die Ou-Testamentiese emet en die Nuwe-Testamentiese aletheia kan met betroubaarheid vertaal kan word, asook met bestendigheid, duursaamheid, onwankelbaarheid, vastigheid en standhoudendheid, maar telkens word hierdie begrippe ten nouste verbind aan God self (vgl Koch 1965:47-55; Kraus 1965:35-46; Quell 1965:232-237; Thielicke 1965:121-122; Wildberger 1978:177-209; Bultmann 1965:241-247; Loonstra 1994:155157). Die kenmerk van die God van Israel is verbondstrou en gevolglik kan 'n mens jou volkome op God verlaat (Deut 32:4; Ps 146:3). God is die "betroubare God wat die verbond in stand hou" (Deut 7:9; vgl Jes 49:7). Gevolglik kan God se wette (Neh 9:13) en werke (Ps 111:7) as "waarheid" beskryf word.

Die Nuwe-Testamentiese boodskap stem hiermee ooreen. Ook hier word die trou van God beklemtoon (Rom 3:3-7). God kan nie lieg nie, maar hou altyd God se woord (Tit 1:2). Die trou van God kom egter op besondere wyse tot uitdrukking in die lewe en werk van Jesus Christus, wat die "ja" is op al God se beloftes (2 Kor 1:20). In God het die Waarheid van God 'n lewende werklikheid geword (Joh 14:16), daardie waarheid wat mense vry maak (Joh 8:32; vgl ook Kok 1957:239-241; Goppelt 1965:80-93). Geen wonder nie dat die Gees wat van die Vader en die Seun uitgaan, die Gees van waarheid genoem word (Joh 15:26) en dat hierdie Gees die kerk in die hele waarheid sal lei (Joh 16:13). Teenoor Christus as die Waarheid staan die Satan as die vader van die leuen, 
ontdaan van enige waarheid (Joh 8:44). Al lê die waarheid op 'n dieper vlak (NGB artikels 25,35), staan dit tog in die nouste verband met Christus self (NGB artikel 33).

Natuurlik moet God in Christus (die Waarheid) in die geloof ontmoet en omhels word (hoewel die waarheid nie in 'n geloofsontmoeting opgaan nie). Hierdie insig hang ook baie nou saam met die Reformatoriese geloofsbeskouing waar geloof, anders as in die Katolieke tradisie, nie opgaan in ' $n$ vir-waar-hou van 'n aantal leerstellings of die verstandelike toestemming van ' $n$ aantal dogmas nie, maar gedefineer word as vertroue in die lewende God.

In die Bybelse getuienis word waarheid nie net met die drie-enige God geïdentifiseer nie, maar ook met die persoon van die mens in verband gebring (Thielicke 1965: 111-122; Smedes 1983:222-224; Velema 1973:69-74). Die Bybelse waarheid is veel meer persoons- as kennis- en saakgerig en daarom het dit altyd die welsyn van die (onskuldige) mens op die oog. Dit werk nie net met "objektiewe feite" soos in die positivistiese benadering nie, maar het 'n ope oog vir die mens in sy of haar konkrete konteks.

\subsection{Die waarheid is proposisioneel}

Met bogenoemde benadering word nie ontken dat die waarheid ook in proposisies uitgedruk kan word nie. Trouens, die uitdrukking "God is Waarheid" is juis ook 'n proposisie, soos ook ander waarhede, byvoorbeeld "God is Skepper", "Christus is Verlosser", "die Gees is Vernuwer". Die standpunt van die relativisme en relasionisme dat die waarheid nie in proposisies uitgedruk kan word nie, is onhoudbaar. Om te sê dat die waarheid onproposisioneel is, is juis ook (bedoel as) 'n waarheidsuitspraak! Kritiek is uitgespreek teen die objektiewe waarheidsbeskouing van die Katolisisme en die ortodoksie en die subjektiewe waarheidsbeskouing van die piëtisme (Sperna Weiland 1968:28-34), terwyl aansluiting gesoek is by ' $n$ meer Bybelse benadering. Indien hiermee saam egter die gedagte laat vaar word dat die waarheid hoegenaamd nie meer proposisioneel verantwoord kan word nie, word juis van 'n belangrike Skrifgegewe wegbeweeg. Juis dan kan dit maklik gebeur dat relasionisme, in sy reaksie teen objektivisme en absolutisme (en die afwysing van 'n proposisionele waarheid), nie die gevaar van subjektivisme en relativisme kan vermy nie. 
Kuitert (1992:23) se bekende uitspraak "alles wat wij over boven zeggen, komt van beneden", verreken nie genoegsaam dat uitsprake van benede deur inspirasie van Bo (deur die Gees van God) ingegee kan word nie. Byvoorbeeld: Niemand kan sê dat Jesus die Messias is as dit nie van Bo ingegee word nie (Matt 16:17).

Bybels gesien is daar geen probleem om van die "ware dogma" te praat en om Bybelse waarhede proposisioneel te verantwoord nie (Bultmann 1965:144; Loonstra 1994:155). Die Bybel praat onbevange daarvan dat die gebooie van die Here waarheid is (Ps 119:86, 151), God se wet is waarheid (Ps 119:142). Verder word ook gepraat van "die ware godsdiens" (Dan 8:12), God se woord wat waarheid is (Joh 17:17), "die waarheid van God" ( 2 Kor 4:2, 13:8) en "die woord van die waarheid" (2 Kor 6:7). "Ons vermag niks teen die waarheid van God nie, maar wel alles vir die waarheid" ( 2 Kor 13:8). Veral in die Timoteus-briewe resoneer hierdie gedagte uitdruklik. So hoor ons dat dit die wil van God is dat alle mense "tot kennis van die waarheid" sal kom (1 Tim 2:4). Ook in 2 Timoteus 3:7 is sprake van "die kennis van die waarheid". Nuwe-Testamenties gesien, is die waarheid identies aan die evangelie van verlossing (Ef 1:13; Kol 1:15).

In die Reformatoriese belydenisskrifte kom die proposisionele waarheidsbegrip ook duidelik na vore. So word die waarheid byvoorbeeld geïdentifiseer met die Heilige Skrif (NGB, artikels 7,8 ) en word daar gepraat van die waarheid van die regverdigmaking en die eenvoud van die Skrif (DLR 1.2.3), asook van die belydenis van die waarheid (DLR 5.1.12). Terloops word hier die opmerking gemaak dat waarheidsproposisies nie almal op dieselfde vlak lê nie. Die waarheid "God is liefde" en "die wind waai wes" en "twee plus twee is vier" lê - as waarhede - op verskillende vlakke - maar daaroor later meer. In hierdie benadering is daar dus ruimte vir objektiewe waarhede.

\subsection{Die waarheid is korrelasioneel}

Wanneer ons sê dat die waarheid korrelasioneel is, word bedoel dat daar ' $n$ wederkerige verhouding (korrelasie) tussen bewering en gebeure/feite bestaan.

Daar is op gewys dat die Griekse denke beheers word deur die korrespondensieteorie. Eintlik het ons hier te doen met 'n universele verskynsel. Almal wil weet wat "die ware feite" is, "wat gebeur het" en sodoende "wat die waarheid is". Nou is dit natuurlik waar dat feite en gebeure nooit op 'n volledige objektiewe wyse weergegee kan 
word nie. Alle weergawes word gekleur deur geloofsinstelling, wêreldbeskouing, wetenskapsvisie, ervaring, leefwêreld, voorbehoude, voor- en afkeure. "Nowhere - not even in the natural sciences - can absolute objectivity be sought by excluding the human subject, the researcher himself. Even the conclusions of the natural scientist and the technician are hermeneutically established" (Küng 1989: 5.10). Twee persone wat byvoorbeeld na dieselfde rugbywedstryd kyk, kan agterna met twee totaal uiteenlopende weergawes daarvan vorendag kom. Oor die hoofsake sal hulle egter saamstem: dát daar 'n wedstryd was, dat punte aangeteken is en wat die eindtelling is. Die weergawe en interpretasie sal verskil, maar oor die gebeurtenis self en kernsake sal ooreenstemming heers.

Die Bybelse waarheidsbegrip staan nie téénoor die Griekse nie, maar verdiep en verbreed dit en is as sodanig voller en ryker. Ook die Bybel ken die begrip waarheid as 'n suiwere weergawe van gebeure, as werklike stand van sake (Bultmann 1965:243; Loonstra 1994:156). 'n Tipiese voorbeeld hiervan is te vind in die optrede van Ananias en Saffira (Hand 5:1-11). Hulle het nie 'n "halwe waarheid" aan Petrus vertel nie maar 'n volle leuen (v3). In hierdie verband moet Romeine 1:18ev gesien word waar sprake is van mense wat die waarheid in ongeregtigheid onderdruk. Efesiërs 4:25 met sy oproep om valsheid af te lê en onder mekaar die waarheid te praat, moet ook in hierdie konteks verstaan word.

Trouens, sonder (ook) hierdie benadering, word alle regspraak - en daaroor handel die negende gebod tog in eerste instansie (Koole 1964: 130-137), totaal onmoontlik (cf Hand 25:1-12; kyk ook Heidelbergse Kategismus 37:101-102, 112). Die regter moet hom of haar immers van alle feite vergewis voordat hy of sy tot ' $n$ billike uitspraak kan kom. Die regter moet in 'n regsgeding nagaan of die boer wat 'n bul verkoop het, doelbewus ' $n$ impotente bul al dan nie verkoop het; die regter moet weet of iemand doelbewus 'n defekte tweedehandse motor al dan nie van die hand gesit het. So moes die Amerikaanse howe die feite verifieer of presidente Richard Nixon en Bill Clintun die feite verdraai, die gebeure verdoesel en so die waarheid geweld aangedoen het.

Sonder hierdie waarheidsbegrip word geskiedeniswetenskap ook 'n onmoontlikheid. Die geskiedenisnavorser probeer die historiese gebeurtenisse so deeglik moontlik nagaan, verifieer en beskryf. Dit word wel nie sonder vooronderstellings gedoen nie 
(soos die positivisme foutiewelik geoordeel het), maar tog so onbevooroordeeld as moontlik. Hiersonder word die evangelieverkondiging ook onmoontlik. Indien 'n betroubare weergawe van die historiese gebeure rondom Israel en Jesus Christus wegval, kom die inhoud van die evangelie self in gedrang. As Christus byvoorbeeld nie opgewek is nie, soos al die apostels getuig (Hand 1:21), dan is ons geloof waardeloos en is ons nog gevange in ons sondes ( 1 Kor 15:17). In hierdie verband moet 'n kritiese opmerking gemaak word oor Bultmann se eksistensiale interpretasie van die evangelie, aangesien dit nie die tema van geskiedenis (Historie) genoegsaam verreken nie en byna met 'n deïstiese Godsbeskouing opereer (vgl Fergusson, 1992). Bultmann reduseer die evangelie. Dit is tipies van die liberale teologie (Bonhoeffer 1970:311-312,360). Dit is opvallend dat van Bultmann se leerlinge van hulle leermeester wegbeweeg het. "Sekerlik is dit so - ook in geheel-en-al historiese sin - dat daar geen evangelie, geen enkele berig, geen brief in die Nuwe Testament, geen geloof, geen kerk, geen erediens, geen gebed in die Christendom tot vandag sou wees sonder die boodskap van die opstanding van Christus nie" (Bornkam 1974:194-195). Anders as bepaalde nuanses van die HTSA (Van Aarde 1996:476500; Pelser 1996:455-475), staan die Gereformeerde Teologie in Suid-Afrika oorwegend krities teenoor die teologie van Bultmann.

\subsection{Die waarheid is multidimensioneel}

Hiermee word bedoel dat daar verskillende nuanses in die waarheidsbegrip is. Smelik (1967:171) praat selfs van verskillende "verdiepings". Daar is byvoorbeeld teologiese waarhede (geloofswaarhede) soos "God is Skepper", "Christus is Verlosser", "die Gees is Vernuwer". Daar is ook logiese waarhede soos $2+2=4$ en $3 \times 3=9$. Daar is ook juridiese waarhede soos "die man is skuldig", etiese waarhede soos "moord is verkeerd" en estetiese waarhede soos "Rembrandt se Nagwag is mooi". Die soortlike gewig van hierdie waarhede is nie almal dieselfde nie en die waarhede lê nie almal op dieselfde vlak nie. Gevolglik kan hulle nie almal op dieselfde wyse geverifieer of gefalsivieer word nie. Hulle het ook nie almal dieselfde relevansie nie. Die waarheid "God is liefde" is byvoorbeeld van veel groot belang as die waarheid "die klip is rond".

Die onderskeiding tussen Goddelike en menslike, ewige en tydelike waarhede mag egter nie in 'n skeiding ontaard nie. So 'n skeiding moet noodwendig uitloop op 'n 
skeiding van geloof en wetenskap, wat onhoudbaar is - maar dit is ' $n$ verhaal van sy eie. Die waarheid van God begrond en fundeer alle menslike waarhede, maak dit juis moontlik en roep dit op.

\subsection{Die waarheid is kontekstueel}

Wanneer beweer word dat die waarheid kontekstueel is, word bedoel dat die waarheid konteks-sensitief is en dat daarmee nie net rekening gehou moet word met die (objektiewe) waarheid nie maar ook met die (subjektiewe) konteks. Hierdie benadering verskil dus van die kontekstualisme, waar die waarheid vanuit die konteks opkom en vanuit die konteks gevorm word. In hierdie verband kan gedink word aan die voorbeeld waarna Bonhoeffer (1966: 390) verwys: kan van 'n kind verwag word om op 'n navraag van sy onderwyser voor die klas te antwoord of dit waar is dat sy vader dikwels dronk by die huis aankom? Smedes (1983:234-237) verwys na 'n ander geval: behoort 'n vrou wat aan haar man ontrou was maar haar ontrouheid ter wille van die behoud van die huwelik laat vaar het, vir haar man daarvan te sê? Reeds eerder is die vraag gestel of ook aan 'n terminale kankerpasiënt die waarheid vertel moet word. Nog 'n voorbeeld: moet ek aan die polisie op navraag die waarheid vertel in verband met 'n (skuldige) moordenaar wat hom iewers op my plaas versteek hou? Moet 'n mens aan die Gestapo die waarheid vertel in verband met 'n (onskuldige) Joodse onderduiker wat weggesteek word? Is die vraag na skuld en onskuld dalk 'n handige kriterium om my optrede te bepaal?

In hierdie verband kan ook gedink word aan die waarheid en leuen van apartheid. Wanneer dinge wat op sigself waar en waardevol is, soos volksidentiteit, kultuurbevordering en taalhandhawing, (oor-)beklemtoon word in 'n konteks van dominansie en diskriminasie (van 'n minderheid teenoor 'n meerderheid), dán word dit verkeerd en uiteindelik 'n leuen. In 'n totaal ander konteks, 'n konteks van gelykberegtiging, demokrasie en vryheid-vir-almal, kan hierdie waardes weer hulle regmatige plek en beklemtoning herwin - te meer indien die meerderheid teen minderhede (bv Afrikaners) sou diskrimineer. 


\subsection{Die waarheid is eksistensieel}

In die Bybelse waarheidsbegrip gaan dit nie net daaroor dat die waarheid geken en bely sal word nie maar ook daaroor dat die waarheid beleef, ja, geleef sal word. Die Psalmdigter sê dat hy deur die trou van die Here leef (Ps 26:3), hy wil "wandel in u waarheid" (Ps, 86:11). Die Nuwe Testament bevestig hierdie benadering. Christus sê aan Nikodemus: "Wie volgens die waarheid handel, kom na die lig toe" (Joh 3:21). In 1 Johannes 1:6 staan daar: "As ons beweer dat ons aan Hom deel het, en ons lewe in die duisternis, lieg ons en handel ons nie volgens die waarheid nie."

Die waarheid is nie net proposisioneel nie maar ook eksistensieel, die waarheid wil nie net geformuleer en geken word nie maar wil ook gedoén en gelééf word. Hierdie dimensie van die waarheid blyk besonder duidelik uit die lewe en werk van Jesus Christus. Sy kruis en opstanding staan duidelik uit as ligbakens van deurleefde waarheid en so as bevrydende waarheid. Die Bybelse waarheidsbegrip is nie net kenteoreties nie maar ook eksistensieel.

\subsection{Waarheidskennis is provisioneel}

Omdat alle menslike kennis beperk en onvolledig van aard is, spreek dit vanself dat ook ons kennis van die waarheid 'n beperkte karakter dra. Dat alle menslike kennis (ook talespraak) provisioneel van aard is, is ' $n$ Skriftuurlike gegewe wat tans ook in die natuurwetenskap (teenoor die pretensie van die positivisme) redelik algemeen aanvaar word (vgl Joubert 1997). Filosofies uitgedruk word van kenteoretiese voorlopigheid gepraat. Bybels geformuleer lui dit so: "Ons ken maar gedeeltelik, en ons verkondig God se wil maar gedeeltelik ..." (1 Kor.13:9). Menslike kennis is gedeeltelik en onvolledig, slegs Goddelike kennis is volledig ( $\mathrm{v} 12$ ). God se gedagtes is baie hoër as menslike gedagtes (Jes 55:9).

Wanneer Szekeres (1970:66) die opmerking maak dat die filosofie en die teologie nie die waarheid in pag het of daaroor kan beskik nie, is dit 'n belangrike opmerking, maar dit kan maklik misverstaan word (vgl ook Sperna Weiland 1968:38). Dieselfde geld vir die opmerking van Kuitert (1994:88): "Geloofstradities beschikken niet over absolute, zelfs niet over onweerlegbare waarheden." Wanneer ons sê dat alle menslike kennis beperk is, bedoel ons nie daarmee dat daardie kennis oneg is nie. Die Here God 
het in die Woord en in Christus genoeg aan die mens geopenbaar om sinvol te lewe en salig te sterwe. In die evangelie van Christus het ons die volle waarheid.

Die benadering van Pannenberg ten opsigte van die waarheidsvraag bevredig myns insiens nie. Pannenberg (1988:50-52) is van mening dat daar nie met die waarheid begin kan word nie en dat die Christelike geloof die waarheidsvraag in 'n totale oop diskussie aan die orde moet stel. Slegs met die finale openbaring van God aan die einde van die tye, met die voleinding van die koninkryk, sal die finale bewys gelewer word van die waarheid in verband met God en Christus (Pannenberg 1988:16, 54-56, 340). Inderdaad sal aan die einde die volle waarheid aan die lig tree, maar Pannenberg gebruik die eskatologie te veel as 'n ontsnappingsmeganisme om aan die klemmende vraag oor waarheid-in-die-hede te ontkom. Die waarheidsvraag word te veel na die eskatologie verskuif. Wie sal dan nog bereid wees om vir die waarheid-hier-en-nou te sterf?

Vanweë die voorlopige karakter van alle menslike kennis, is 'n ekumeniese en dialogiese benadering baie belangrik (die begrip dialogiese waarheid is te swaar belas om sinvol gebruik te word). In Efesiërs 4:18 lees ons dat ons "saam met al die gelowiges in staat sal wees om te begryp hoe wyd en ver en hoog en diep die liefde van Christus strek." Nie net ten opsigte van dogmatiese kwessies nie (soos bv die diskussie oor die versoeningsleer wat tans aan die gang is) maar ook ten opsigte van etiese vrae (soos bv kloning) is internasionale teologiese en kerklike diskussie van die allergrootste belang. Individuele teoloë en kerke moet nie te gou dink dat hulle die volle waarheid ontdek het nie. Gesamentlike besinning en voorbidding en selfs besluitneming onder leiding van die Gees en in die lig van die Woord, is onmisbare elemente vir 'n gesonde teologie-beoefening en kerklike ontwikkeling.

In hierdie verband kan gedink word aan die enorme bydrae van die kant die Gereformeerde Ekumeniese Sinode ten opsigte van die rassevraagstuk in Suid-Afrika. Sonder hierdie belangrike insette van gereformeerdes oor die wêreld sou Afrikaanse kerke maklık 'n sektariese rigting ten opsigte van veral kerklike verhoudings kon opgegaan het. Hier kan spesifiek verwys word na die volgende uitspraak: "The RES declare that the ideology of apartheid ... is therefore a heresy and the biblical justification of it is a heresy" (vgl GKSA 1991:160). 


\section{KONKLUSIE}

Daar is by talle teoloë wêreldwyd 'n behoefte om weg te stuur van absolutisme en relativisme, van fundamentalisme en modernisme en om na 'n ander antwoord vir die waarheidsvraag te soek, 'n antwoord naamlik waarin rekening gehou word met die multidimensionele karakter van die waarheid. Die Bybelse waarheidsbeskouing word telkens verwring indien dit onder net een noemer tuisgebring word. Die waarheid is nie maar net 'n proposisie nie, 'n leerstuk nie, maar veral 'n persoon: God, Christus, die Gees. Aldus vra die waarheid om 'n persoonlike geloofsontmoeting met hierdie drie-enige God, die waarheid vra om oorgawe, vertroue, gehoorsaamheid, diens. Die waarheid vra om bely én gedoen te word. Die waarheid vra om betroubaar en waaragtig te lewe, om as Christene die waarheid te praat, maar só dat steeds rekening gehou word met die wisselende omstandighede en konkrete kontekste waarin mense, geskape na die beeld van God, hulle bevind. Die waarheid is sensitief vir God, vir mense, vir dogmas, vir feite, vir kontekste. Die waarheid erken ook dat menslike kennis onvolkome en onvolledig is. Die waarheid is dus beskeie en, soos die liefde, nie grootpraterig en verwaand nie.

Uiteindelik is die waarheid sensitief vir die liefde. Soos wat die liefde verheug is oor die waarheid (1 Kor 13:6), so is die waarheid bly oor die liefde. Die waarheid kan immers slegs dan behoorlik funksioneer indien "die waarheid in liefde betrag word" (Ef 4:15). "Waarheid sonder liefde is brutaliteit en liefde sonder waarheid is sentimentaliteit" (Heyns 1986:117). Anders gesê: waarheid sonder liefde versand in ortodoksisme en liefde sonder waarheid vervloei in emosionalisme.

\section{Literatuurverwysings}

Bornkamm, G [1956] [1975]. Jesus van Nasaret. Kaapstad: Teologiese Seminarie van die Broeder-kerk in SA.

Brümmer, V 1975. Wijsgerige begripsanalyse: Een inleiding voor theologen en andere belangstellenden. Kampen: Kok.

Brunner, E [1938] 1963. Wahrheit als Begegnung. Zürich: Zwingli-Verlag.

Bonhoeffer, D 1966. Ethik. Kaiser: München. 
Bonhoeffer, D 1970. Widerstand und Ergebung: Briefe und Aufzeichnungen aus der Haft. Neuausgabe. Hrsg E Bethge. Kaiser: München

Bultmann, R 1965. sv aletheia. Theological Dictionary of the New Testament, I.

Buys, P W 1976. Die botsing van pligte as etiese vraagstuk. Potchefstroom: PUCHO.

Calvijn, J s a. Het gepredikte Woord: Preeken van Johannes Calvijn, IV: Preeken over den dekaloog, vert deur J Douma \& W H Van der Vegt. Franeker: Wever.

Calvin, J 1949. Commentaries on the book Joshua, tr by H Beveridge. Grand Rapids: Eerdmans.

Carney, F S 1991. The structure of Augustine's ethic, in Babcock, W S (ed), The ethics of St Augustine, 11-37. Georgia: Scholars Press,

Curley, A J 1997. Augustine's critique of scepticism: A study of the Contra Academicos. New York: Peter Lang.

De Bruyn, P J 1998. Die Tien Gebooie. Potchefstroom: PUCHO.

Du Toit, C W 1997. The end of truth? HTS 53(4), 939-955.

Douma, J 1987. De Tien Geboden, III. Kampen: Van den Berg.

- 1997. Medische ethiek. Kampen: Kok.

Durand, J J F 1977. Waarheid en leuen in 'n terminale situasie - 'n Dogmaties-etiese besinning in Woord en wetenskap. Gedenkbundel aan prof dr F J M Potgieter, 73-80. Bloemfontein:VCHO.

Eisler, R 1910. Wörterbuch der philosophischen Begriffe, III. Berlyn: Königliche Hofbuchhandlung.

Ferguson, D 1992. Bultmann. Londen: Cassell.

Geesink, W 1931. Gereformeerde ethiek, I. Kampen: Kok.

GKN 1980. God met ons ... over de aard van het Schriftgezag. Leusden: Kerkinformatie.

GKSA 1991 Handelinge van die vier en veertigste nasionale sinode te Potchefstroom. Potchefstroom: Administratiewe Buro. 
Goppelt, L Wahrheit als Befreiung, in Müller-Schwefe, H-R, Was is Wahrheit? Ringvorlesung der Evangelisch-Theologischen Fakultät der Universität Hamburg. Göttingen: Vandenhoeck \& Ruprecht.

Heyns, J A 1970. Die nuwe mens onderweg: Oor die Tien Gebooie. Kaapstad: Tafelberg.

- 1986. Teologiese etiek: Sosiale etiek. Pretoria: NG Kerkboekhandel.

Holwerda, B 1975. De dingen die ons van God geschonken zijn: 52 Catechismus-predikatiën. Goes: Oosterbaan \& Le Cointre.

Horn, C 1995. Augustinus. München: Beck.

Joubert, G 1997. Die groot gedagte: Abstrakte weefsel van die kosmos. Kaapstad: Tafelberg.

Kirwan, C 1999. Avoiding sin: Augustine against consequentialism, in Matthews, G B, The Augustinian tradition, 183-194. Berkeley: University of California Press.

Koch, K 1965. Der hebräische Wahrheitsbegriff im grieschischen Sprachraum, in Müller-Schwefe 1989:47-65.

Koole, J L 1964. De Tien Geboden. Baarn: Bosch \& Keuning.

Kraus, H J 1965. Wahrheit in der Geschichte, in Müller-Schwefe 1989:35-46.

Küng, H \& Tracy, D (ed) 1989. Paradigm change in theology: A symposium for the future. Edinburgh: T \&T Clark.

Kuitert, H M ??? Het algemeen betwijfeld Christelijk geloof: Een herziening. Baarn: Ten Have.

- 1994. Zeker weten: Voor wie geen grond meer onder de voeten voelt. Baarn: Ten Have.

Lee, B M 1979. Mendacium officiosum: Een beoordeling van de zgn. "noodleugen", met speciale aandacht voor Augustinus' opvattingen. Groningen: De Vuurbaak.

Loader, J A 1988. "Die waarheid is eties": Oor die Skrifbeskouing van die Etiese Teologie. In die Skriflig 22(86), 42-55.

- 1996. 'n Hervormde tradisie as heelmiddel. HTS 52(4), 566-589. 
Lochmann, J M 1979. Wegweisung der Freiheit: Abriss der Ethik, in Der Perspektive des Dekalogs. Gütersloh: Gütersloher Verlagshaus Gerd Mohn.

Loonstra, B 1994. De geloofwaardigheid van de Bijbel. Zoetermeer: Boekencentrum.

Maimela, S S 1988. Doing theology in South Africa after the Kairos Document in Mouton, $\mathrm{J}$ et al (eds), Paradigms and progress in theology, 321-334. Pretoria: HRSC.

Mann, W E 1999. Inner-life ethics, in Matthews, G B (ed), The Augustinian tradition, 140-165. Berkeley: University of California Press.

Möller, J 1971. Wahrheit als Problem: Traditionen - Theorien - Aporien. München: Erich Wewel.

Müller, H-P 1989. Was ist Wahrheit? Stuttgart: Kohlhammer.

Oberholzer, J P 1993. Die teologiese eie-aardigheid van die Nederduitsch Hervormde Kerk: Vrae en nuanses. HTS 49(4), 870-886.

Pannenberg, W 1989. Systematic theology, I. Edinburgh: T \& T Clark.

Pelser, G M M 1997. Rudolf Bultmann oor die opstanding van Jesus. HTS 53(3), 455475 .

Pop, F J 1957. Bijbelse woorden en hun geheim: Theologische verklaring van een aantal Bijbelse woorden, $I$. 's-Gravenhage: Boekencentrum.

Quell, G 1965. sv emet. TDNT, I.

Rief, J 1961. Liebe zur Wahrheit: Untersuchungen zur Ethik des jungen Augustin. Theologische Quartalschrift 141, 281-318.

Rist, J M 1999. Augustine: Ancient thought baptized. Cambridge: Cambridge University Press.

Smedes, L B 1983. Mere morality: What God expects from ordinary people. Grand Rapids: Eerdmans.

Smelik, E L 1967. De ethiek in de verkondiging: Moraal zonder moralisme. Nijkerk: Callenbach. 
Sperna Weiland, J 1968. Waarheid, in Heering, H J et al (reds), Dogmatische verkenningen, 28-39. 's-Gravenhage: Boekencentrum.

Stock, B 1998. Augustine the reader: Meditation, self-knowledge, and the ethics of interpretation. London: Harvard University Press.

Szekeres, A 1970. Waarheid, in Van der Woude, A S et al (reds), Kernwoorden in het christelijk geloof, 61-68. Kampen: Kok.

Thielicke, H 1965. Theologische Ethik 2,1: Mensch und Welt. Tübingen: JCB Mohr (Paul Siebeck).

Van Aarde, A 1996. Die historiese ondersoek na Jesus van Nasaret in perspektief. HTS 52(2), 476-500.

Van Huyssteen, W 1986. Teologie as kritiese geloofsverantwoording: Teorievorming in die sistematiese teologie. Pretoria: RGN.

Van Wyk, D J C (snr) 1998. Wortels en agtergronde van Hervormde teologie en kerkwees in Suid-Afrika. HTS 54(1\&2), 245-263.

Van Wyk, D J C (snr) 1999. Die ander opsie: Kohlbrugge - Hoedemaker - Barth. HTS 55(1), 120-151.

Van Wyk, J H 1967. By die sterfbed. Die Kerkblad 70 (1928), 8-9.

- 1986. Gesindheid en gestalte. Pretoria: NG Kerkboekhandel.

- 1989. Die Woord is waardevol: 'n Dogmatiese besinning oor die Reformatoriese Skrifbeskouing. Potchefstroom: PUCHO.

- 1998. Etiek in eenvoud: Gesprekke oor morele vraagstukke. Potchefstroom: PTP.

Velema, W H 1971. Rondom het levenseinde: Ethische en pastorale overwegingen. Kampen: Kok.

- 1973. Leer ermee te leven! Kampen: Kok.

Vennix, A C M 1998. Wat is waarheid? De virtus quaestionis in het licht van Thomas van Aquino. Best: Damon.

Volten, $\mathrm{H}$ sj. Het negende gebod, in Besselaar, A T et al (reds), De thora in de thora, II. 130-166. Franeker: Wever. 
Vrielink, J H 1956. Het waarheidsbegrip: Een theologische onderzoek. Nijkerk: Callenbach.

West, G 1991. Biblical hermenuetics of liberation: Modes of reading the Bible in the South African context. Pietermaritzburg: Cluster.

Wildberger, H 1978. sv 'mn, fest, sicher. Theologisches Handwörterbuch zum Alten Testament, I.

Wurth, G B 1957. Het christelijk leven: Grondlijnen der ethiek. Kampen: Kok.

\section{AUGUSTINUS}

Latynse tekste

Bauer, J B, (ed) 1992. Corpus Scriptorum Ecclesiasticorum Latinorum. Wenen: HölderPichler-Tempsky.

Migne, J-B, (ed) 1841-1842. Patrologiae Cursus Completus. Parys: Migne.

Vertaalde tekste

386 Contra Academicos:

St. Augustine “Against the Academics”, in O'Meara, J J, tr 1951. Ancient Christian writers 12. New York: Newman Press.

386 De beata vita

Augustinus: Over het gelukkige leven, vert deur R Ferwerda in 1999. Baarn: Agora.

\section{Soliloquia}

Augustine: Earlier writings, tr J H S Burleigh in 1953. Philadelphia: Westminster Press.

389 De vera religione:

Augustine: Earlier writings, tr by J H S Burleigh in 1953. Philadelphia: Westminster Press. 
394 De mendacio:

Augustine: De mendacio, in Schaff, P (ed) 1978. Nicene and Post-Nicene fathers of the christian church, III, 457-477. Grand Rapids: Eerdmans.

396-426 De doctrina Christiana:

Saint Augustine: On Christian Doctrine, tr by D W Robertston in 1958. New Work: Macmillan.

397-401 Confessiones:

Augustinus : Belijdenissen, vert deur A Sizoo in 1965. Utrecht: Het Spectrum.

400-420 De Trinitate

Augustine, Saint. 1990. The Trinity, tr by E Hill. Brooklyn/New York: New City Press.

420 Contra mendacium:

Augustine: Contra mendacium, in Schaff, P (ed) 1978. Nicene and Post-Nicene fathers of the christian church, III, 481-500. Grand Rapids: Eerdmans.

421-423 Enchiridion

St. Augustine: The Enchiridion on faith, hope and love, tr by $\mathrm{H}$ Paolucci 1987. Washington DC: Regnery Gateway.

426-427 Retractiones

Perl, C J 1976. Aurelius Augustinus: Die Retractionen in zwei Büchern (Retractionum libri duo). Paderborn: Ferdinand Schöningh. 